This item was submitted to Loughborough's Research Repository by the author.

Items in Figshare are protected by copyright, with all rights reserved, unless otherwise indicated.

\title{
Gender, new creativity and Carnatic music in London
}

PLEASE CITE THE PUBLISHED VERSION

https://doi.org/10.1080/19438192.2019.1568663

PUBLISHER

(c) Taylor and Francis

VERSION

AM (Accepted Manuscript)

PUBLISHER STATEMENT

This is an Accepted Manuscript of an article published by Taylor \& Francis in South Asian Diaspora on 18 January 2019, available online: http://www.tandfonline.com/10.1080/19438192.2019.1568663.

\section{LICENCE}

CC BY-NC-ND 4.0

\section{REPOSITORY RECORD}

Hornabrook, Jasmine. 2019. "Gender, New Creativity and Carnatic Music in London". figshare. https://hdl.handle.net/2134/36737. 


\title{
Gender, New Creativity and Carnatic Music in London
}

\section{Jasmine Hornabrook}

\begin{abstract}
This article examines creative projects amongst second-generation, Tamil diasporic female musicians (focused on British Sri Lankan examples) located within London's Carnatic music scene. Several scholars have suggested that the twentieth-century Indian nationalist project constructed ideals of femininity that positioned women to uphold the inner core of Indian culture as bearers of tradition during colonial rule (Bakrania 2013; Chatterjee 1989), and which were also reflected in the restricted performance and creativity of Carnatic music for female musicians (Subramanian 2006; Weidman 2003). This article focuses on second-generation musicians, who combine their Carnatic background and 'South Indian' sound with other everyday sounds in Britain. Their creative projects shift from an aesthetic that was responsive to colonialism in India to highlight female creativity and hybridity in decolonizing processes. This article presents examples of how cultural expectations of women as bearers of tradition are decentred, repositioning them as creative agents in a transnational diaspora.
\end{abstract}

Keywords, gender, creativity, Carnatic music, Tamil diaspora, female musicians

\section{Author biography}


Jasmine Hornabrook is an ethnomusicologist focusing on music, transnational networks and identity in South Asian diasporas. She is interested in how cultural practices facilitate a sense of belonging and identity across nation-state borders. She completed her doctoral research at Goldsmiths, University of London, and examined music and migration in the Sri Lankan Tamil diaspora. Jasmine works on the Leverhulme-funded project 'Migrant Memory and the Postcolonial Imagination' in the School of Social Sciences at Loughborough University.

In her review for the Carnatic music-inspired performance, Subduction Zone, Seetal Kaur wrote: “There are some stories that get swept under the rug. Perhaps there aren't enough opportunities to express them, or there is an assumption no-one is listening ... The unique and complex identity of British Tamils is one of the stories that are often hidden ... but now the next generation is unfolding the richness of their refined cultural traditions and combining them with their equally strong urban influences" $(2016,22)$. Subduction zone is the story of a British-Tamil woman growing up in East London, expressed through Carnatic South Indian classical music, along with North Indian Hindustani and British pop music, South Indian classical dance and street dance. The performance explored experiences of growing up in diasporic settings, facing competing cultural interests and tackling discrimination and sexism. Through the sounds of the veena (lute), Carnatic songs, guitar and live electronics, the unique and shared stories unfolded. The performance was curated by a second-generation, Carnatic musician, who learned the South Indian veena as part of her Tamil upbringing. Her creativity, expression and experimentation through the performance was in sharp 
contrast to the cultural expectations and ideals of South Asian femininity, such as that of restrained female musicianship that emerged in the context of British colonialism in India.

This article looks at emerging creative projects among second-generation female musicians within Tamil, focusing on Sri Lankan, diasporic communities. First it introduces the Carnatic music scene in London, discussing musical practices among the diasporic second-generation. Carnatic music is an integral feature of a constructed Sri Lankan Tamil cultural identity that emerged in the face of ethnic persecution, and connecting with Tamil Nadu in India in an act of Tamil cultural and ethnic solidarity. Despite being geographically associated with the whole of the South of India, the Carnatic music scene in London was largely the result of the displacement of thousands of Tamil people from Sri Lanka from the late 1970s. A brief discussion follows on the Indian nationalist project and the position of women as 'bearers of tradition', and on how ideas of 'ideal femininity' developed in Carnatic music, which are being challenged in the Tamil Diaspora. Finally, the article argues, through looking at two artists in London, that female artists in diasporic settings are emerging as creative agents amid a music scene that retains ideals instated during the British colonial era. While the mention of female second-generation Sri Lankan Tamil musicians brings to mind artists such as the rapper M.I.A, the discussion here is on artists who have significant involvement with Carnatic music in the UK and in India. The first artist is Mithila Sarma, the veena player behind Subduction Zone and various other projects using the veena in recontextualized settings. The second is Abi Sampa, who juxtaposes her South Indian and Euro-American vocal styles and recontextualizes Carnatic compositions on the electric veena. Their musical projects contribute to the visibility of women's roles in Carnatic music in a postcolonial diasporic context in the decolonizing era.

In her book of interviews with female Indian musicians, dancers and painters, C. S. Lakshmi suggests that looking exclusively at female artists could be an essentialisation of their gender or 
their art, but can be portrayed also as a kind of counter-culture of matriarchal aesthetics (2000, viii). Looking at creative projects among female musicians, who learn Carnatic music as part of their Sri Lankan Tamil heritage is necessary, not only because second-generation female musicians are proactive in the field, but also because the majority of literature on British South Asian music focuses on the male-dominated styles of Bhangra and Asian Underground (Bakrania 2013, Murthy 2009, Shukla 2003). Complex identity politics, and intergenerational, class, caste and gender gaps are key themes in this literature. Falu Bakrania states that, within Bhangra, male DJs dominate with women only appearing as vocalists on various tracks and as Bhangra references folk styles, it is associated with the working class $(2013,6)$. Asian Underground, on the other hand, is more gender neutral and is associated with the middle classes because of its use of classical South Asian music (ibid).

Bakrania's fieldwork was carried out in the late 1990s and twenty years later the 2018 British South Asian Alchemy festival - held in London's Southbank Centre - included a day of curated events by Shaanti, a British-South Asian production company focusing on issues of inequality. The events showcased British South Asian female musicians, DJs and writers and to promote gender equality and opportunities for women working in music. Such focus on new creative projects by female musicians is timely.

Creativity is deeply intrinsic to Carnatic music. Manodharma sangeetham, or 'creative music' in Sanskrit, refers to the rule-bound improvisation in Carnatic music. Carnatic music is highly standardised - with musicians strictly following conventions of performance, instrumentation, the use of raga melodic frameworks, and standardised repertoire, and the style is surrounded by discourses of musical purity. Within Carnatic music scenes, 'fusion' often describes both a creative process and an emerging popular genre expanding beyond the rigid rules of manodharma sangeetham, as well as Carnatic music more broadly, which incorporates individual creative ideas, popular music and explicit non-South Asian or 'global' musical influences. 'Fusion' is contested, however; hence the term 'new creativity' is used in this article to refer to individual, 
non-Carnatic creative processes, i.e. creative processes informed by the music that is heard on an everyday basis - through Carnatic music lessons, on the radio, in the temple - and appropriated in various, 'non-rule based' ways by the musicians. 'New creativity' is thereby distinguished from the established creative concept of manodharma sangeetam and opens up to broader ideas of creative transformations.

\section{Carnatic music in London}

Seetal Kaur's observation that the story of British Tamils is often hidden is reflected in my extensive fieldwork in London with the Tamil Diaspora. Tamil cultural events, such as concerts by world-class Carnatic music artists, take place in temple basements, school halls and suburban theatres and are often only promoted within Tamil diasporic networks and in the Tamil language. As the island nation went through severe ethnic tensions throughout the twentieth century, Tamil cultural nationalism was consolidated and symbolised by the practice of the Tamil language, Carnatic music, bharatanatyam dance and Hindu religion. Many of Sri Lanka's Tamils looked to India for solidarity. India was referred to as 'Mother India' in Tamil Sri Lanka and as an ethnolinguistic, spiritual and cultural home (Russell 1982, 136). Chennai, the capital of Tamil Nadu, became a significant centre of Tamil politics, culture and music from the early twentieth century onwards (see Daniel 1996; Reed 2010; Wilson 2011), and many aspiring Sri Lankan Tamil musicians studied music there. Mass forced migration from Sri Lanka took place after the devastating anti-Tamil riots of July 1983, which resulted in civil war, and lasted until May 2009. The forced migration created a highly-dispersed diaspora, stretching from India, Southeast Asia, Australia and North America to the UK and other European nations, which has been active in establishing cultural and religious organisations. Forced migratory experiences resulted in a strong desire to upkeep Tamil community cohesion. Through music and other cultural practices, my 
research participants have explained that this is a way of 'becoming one again' after the 'scattering' of Tamil migration; diasporic gatherings are facilitated by common cultural practices performed concurrently in multiple locations around the world (see Hornabrook 2017).

While Carnatic music and bharatanatyam dance were significant cultural markers in twentieth-century Sri Lanka, many of the first generation practitioners in the UK were unable to learn or complete their training due to the troubles on the island. The second generation is encouraged to connect to their Tamil heritage through participation in Tamil supplementary schools, where many study Tamil language, Carnatic music, bharatanatyam dance and Saiva Hinduism. As a result, there is a significant generational gap between the first and second generation in terms of musical and dance education and experiences of learning and performance. Carnatic music pedagogy in the UK is based on the same 500-year-old learning system that is used in India, Sri Lanka and in other diasporic sites. Purandara Dāsa (1484 - 1564) composed graded musical exercises to teach Carnatic music and these exercises form the basis of musical tuition today. Young students are trained primarily through lessons from the 'blue book', a series of foundational exercises and basic songs designed to combine tala rhythmic cycles, raga and ornamentation, and lyrics (Panchapakesa Iyer 2008). The voice or instrumental style is trained to acquire the 'correct' sound through varishais, sequences for singing/playing in rhythm, cultivating ornamentation and extending vocal range, and swaram, composed syllabic passages, often in the seven-note Carnatic raga mayamalavakoulai. Over time, these exercises shape the voice and/or playing style so that there is a flow between each note, rather than accenting each individual step of the raga. Students progress to sing or play compositions, such as Geethanams, Varnams and Kirthanams, in various raga and talam and often in line with the graded syllabus of exam boards such as Oriental Examination Board London, Oriental Fine Arts Academy of London and Academy of Fine Arts (London). Musical skill is developed throughout the student's musical education, through such exercises, graded songs, and imitation of the guru's singing or playing, with gamakas, 
or ornaments, integral in achieving the correct sound and aesthetic. Sarma observes that learning Carnatic music in the UK was not just about learning the musical system and style, it was a way that parents hoped would impart elements of Tamil culture:

So that means I don't just learn sa ri ga ma pa dha ni sa. I learn what to wear, I learn how to respect my instrument, I learn how to act around my instrument, how I should act when I perform, what I should do, how I should perform my repertoire, what starts, what ends, my religious beliefs are based around my compositions or how I devote which song to which god at which time during the performance, so you learn it as a whole kind of package of culture, tradition, religion and everything else. I don't think there's anything wrong with it but it is kind of what we're fed and we're actually conditioned in a certain way we think 'Carnatic music' (Mithila Sarma, personal communication, November 2016).

As Sarma suggests, Carnatic music became an integral part of a constructed and essentialised Tamil diasporic culture passed onto the second generation, reflecting Sri Lankan Tamil cultural nationalism during the twentieth century. As a result, musical participation is fairly balanced between male and female students, although gender divisions do remain for certain practices and instruments. For instance, very few female students learn the mridangam doubleheaded barrel drum and few male students learn the veena. The violin, flute and vocal tuition is balanced in terms of gender participation, whilst bharatnatyam dance is predominantly learned by female students.

A significant, although voluntary, part of the learning process in the UK is the performance of an arangetram - a lavish debut performance ceremony consisting of the student's first full concert accompanied by professional musicians and symbolising the beginning of a young musician's career. Arangetrams are often regarded as graduation ceremonies in diasporic contexts 
and it is quite rare that the student pursues their musical career, despite having performed a ceremony that costs their family tens of thousands of pounds. Unlike dance arangetrams, music arangetrams are relatively balanced in terms of male and female participation. The dancer and scholar, Priya Srinivasan refers to the dance arangetram in the United States as having a dual function: first, to teach "young Indian American girls to become ideal Indian women cultural citizens" and, second, to demarcate difference in American multicultural discourse and society (2012, 142-43). The arangetram is a means of demarcating difference and asserting Tamil cultural identity in multicultural Britain, but the music arangetram does not emphasise the transition of Sri Lankan British girls into ideal South Asian women, as is the case of the dance ceremony in the USA. Nevertheless, the high participation by London's Sri Lankan Tamil families in the arangetram symbolises a commitment to Tamil cultural continuity. A South-London-based music teacher told me that,

In this country, this [the arangetram] is the one thing the Sri Lankans are doing [a lot] because of what we are missing. We are missing our part of the country, our culture ... we are scared of losing our traditions, so we are unlimited in the way we are pushing our children. Our generation has lost a lot, education, wealth, independence, happiness, our aims; our life in a way. We had been living in our country, our land, we had to depart from that part of the country and make a new life, so we are scared of losing our culture (anon. personal communication)

The arangetram is also a significant marker in terms of the creative agency of young musicians. A prominent veena teacher in North London told me that the arangetram is the point at which the student gains the guru's blessing to experiment musically. She said the arangetram symbolised the completion of her student's training with her, therefore she gives her blessing to them to experiment with their performance style (personal communication, October 2012). The arangetram is widely 
performed by second-generation musicians, including the two musicians I refer to in the examples later, and is thus a significant part of the pedagogic process towards forging a new creativity.

The arangetram ceremony originates from the female temple artisans, or devadasis, who were custodians of music and dance and intrinsic to ritual worship in the temples of South India. Under colonial rule, devadasis were considered immoral and regarded as prostitutes as they were financially supported by wealthy patrons and therefore contrary to ideas of morality and female respectability in society and in music (Subramanian 2006, 120-21). The devadasi act of 1947 was brought in to abolish the artisan - patronage system. With this, the original custodians of the classical arts were eliminated under colonial rule. Music and dance were re-introduced as the recreations of urban middle-class Brahmin girls to enhance matrimonial potential and display ideals of South Asian femininity.

Carnatic music has a long history, from its origins in the Sanskrit Vedas and the Tamil pannisai music system to its current presence in South Asian diasporic culture, yet it was deeply impacted by British colonialism. Partha Chatterjee (1993) argues that there were two domains of Indian nationalism in the face of British colonialism: the inner, or spiritual sphere, and the outer, material, sphere. The spiritual sphere represents the inner self and the social space of the home, “imagined to be India's uncolonized interior" (Weidman 2006, 146), while the material sphere reflects the world, the outer self and the direct influence from colonialism. Therefore, the material elements of 'modern Western civilization' were combined with the distinct "spiritual essence of the national culture" (Chatterjee 1989, 623-24) to create a 'modern' India while retaining its spiritual core. These worlds placed women within the inner, spiritual domain and ideals of femininity positioned women to uphold the inner sphere of Indian culture as the "bearers of tradition", and as Falu Bakrania states, their "performance of femininity [w] as equivalent to national survival" (2013, 17). The practice of Carnatic music and bharatanatyam dance by middle-class Brahmin girls and 
women was a significant part of this performance of femininity and bearing of tradition. Lakshmi Subramanian argues that Carnatic music lay at the heart of an Indian sovereignty that was not open to any negotiation or compromise in the twentieth century $(2006,17)$. Despite being placed within the inner, spiritual sphere of the Indian nation, contemporary Carnatic music reveals deep colonial influences. With colonial administration, Carnatic music underwent urbanisation moving from the temples and courts of Tanjore to the Brahmin-dominated music institutions of Madras, now Chennai. Subsequently, Carnatic music was consolidated as a classical genre, to stand as an Indian equivalent to the classical music of Europe. This consolidation project included the emphasis on written sargam notation, the concert hall performance format and refining and standardising repertoire (Subramanian 2006, 84), notably through the hailed institution of the Madras Music Academy. Carnatic music has retained the characteristics it acquired during the colonial era in South India's and Sri Lanka's postcolonial Diasporas.

In her book The Singer and the Song, C. S. Lakshmi and her female Carnatic musician interviewees note how their gender has created limitations in their artistic careers (2000). A number of the interviewees remain active in the South Indian music scene in India and around the world and a number of high-profile female artists speak about continued gender inequality in Indian media.

The next section looks at two lasting aspects of the Indian nationalist project on Carnatic music and gender, and how these are being challenged in the diasporic South Indian music scene, before moving onto two detailed examples of new creativity in Carnatic music by Mithila Sarma and Abi Sampa.

The Voice, Devotion and Ideal Femininity 
The voice in particular was impacted by the Indian nationalist project. Symbolising "authenticity" and "Indianness", the voice is central in Carnatic music with melodic instruments, particularly the European violin, introduced during the colonial era, emanating a vocal quality in their performance. Amanda Weidman suggests the contemporary Carnatic vocal style is a 'distinctly modern and postcolonial desire' to create a 'natural and authentic' Indian sound, and that it is 'a metaphor for a tradition and a self that have survived colonialism' $(2006,57)$. She suggests that during the twentieth century it was not just a certain kind of voice that was valued, but the voice itself, 'identified with chaste womanly behaviour, [which] came to be privileged as karnatic music's locus of authenticity' (Weidman 2003, 195). This voice was encapsulated by M. S. Subbulakshmi, who was from a Devadasi family but showed the domesticity, 'sublime devotion' and Indian womanhood desired by Indian nationalism. The naturalness and beauty of the voice conveys the emotion of bhakti divine devotion and was gendered as female, reflecting gendered notions of sublimity and beauty from Euro-America (Weidman 2003, 208). Revered as the Nightingale of India, M. S. Subbulakshmi is known for her rendering of Carnatic and devotional repertoire, her focused performance as bhakti devotion, her traditional attire and her seamless, ornamented vocal performance. In her performance of 'Nagumomo Kanaleni' by the eighteenth-century saintcomposer, Thyagaraja, Subbulakshmi sings through the song in her highly-ornamented style in the piece's raga abheri, without deviation from the raga or the melodic character of the song (see Subbulakshmi 2008). Subbulakshmi's voice is accompanied by her female students, the violin, the mridangam drum and ghatam clay drum.

M. S. Subbulakshmi represented 'Indian womanhood' and domesticity: as a housewife who made flower garlands for the pooja room and knew nothing but music (Weidman 2003, 136). It is interesting to note, however, that M. S. Subbulakshmi came from the exact devadasi community of music and dance custodians that were so-called immoral and ostracised during colonial rule. There has been recent controversy within Carnatic music circles when the Carnatic vocalist and social 
activist, T. M. Krishna, publicly questioned whether M. S. Subbulakshmi's voice would have been the regarded the way had she not behaved as a Brahmin woman, marrying a Brahmin man and fulfilling the constructed ideals of South Asian femininity (Deccan Chronicle, no author given, 2017). Krishna's questions were received with outrage on the most part, but some readers concurred and suggested that such questions are significant for the challenge of gender and caste inequality in Carnatic music. Priya Srinivasan has also brought M. S. Subbulakshmi's background to the fore in her piece 'Becoming Subbulakshmi', a 'talking dance' which positions archival recordings of Subbulakshmi's voice with the history of her background, problematising the discrimination of devadasis in direct relation to the celebration of Subbulakshmi's voice (Srinivasan 2016).

As part of the concepts of 'Indian womanhood' and 'female respectability', female artists were expected to show divine rather than human love, therefore their performance should show restrained devotion, rather than demonstrate sringara rasa - erotic sentiment, sensual experience, or raw passion. This ideal has been challenged by the experimental singer and composer, Susheela Raman. She uses the Carnatic and Tamil devotional songs she learned growing up in a South Indian family in the UK and in Australia in experimental arrangements, and in doing so she veers away from ideas of South Asian femininity and restrained devotional demeanour. Raman's arrangements of Carnatic songs demonstrate new creativity as she fuses and transforms the pieces far beyond the rule-bound practice of manodharma sangeetham. Her performance is controversial amongst the Carnatic music scene because of her unconventional pronunciation and treatment of raga, her nonSouth Indian vocal style and her highly passionate on-stage performance. Provoking a great deal of response, a number of South Indian music enthusiasts credit Raman for her adaptation and spread of Carnatic compositions to a broad audience on the one hand. ${ }^{1}$ On the other, her arrangements of Carnatic music and her on-stage movement have come under great scrutiny from some Hindu devotees and rasika music lovers. While Raman's style divides the crowd in London's music scene, 
even amongst the second generation, it demonstrates the highly emotive responses to her creative treatment of Carnatic music, which are based on her being a female artist.

\section{Limits of Musical Creativity}

The esteemed female vocalist, D. K. Pattamal, performed highly virtuosic forms in the face of male occupancy of the Carnatic music scene in the twentieth century. Despite her reverence, she was subjected to 'unjust opposition' as she sang the pallavi form and virtuosic kalpana swaram improvised passages using the solfege sargam notes - that were considered male territories. She suggested that many male musicians would not accompany female musicians as 'certain territories are sacrosanct and women must not enter them', while others held the opinion that '[w]omen have sweet mellifluous voices. Let them sing ragas and kirthanas and padams. Why do the ladies trouble their pretty little heads over things like kalpana svaras, which require brainwork!' (D. K. Pattammal cited in Lakshmi, 2000, xxxii). Musically, female artists were not supposed to imitate the creativity and virtuosity of male musicians in concerts but instead to perform raga alapana, semi-classical and classical compositions without the virtuosic, complex improvisation that has come to characterise Carnatic music (Weidman 2003, 215). According to this discourse, the extended and competitive ragam thanam pallavi form should not be performed by female artists as it is a display of technique and skill. This is largely disregarded by female artists in Chennai now but Weidman argues this musical 'uneventfulness' is part of the aesthetic production; 'nothing out of the ordinary is supposed to happen' $(2006,135)$. While many high-profile female Carnatic musicians demonstrate great virtuosity and inventiveness, their performances, gestures and on-stage personas are often distinct from the extravagant performances of male artists such as Sanjay Subramaniam, the Mysore Brothers and Shashank Subramanyam. 
The London-based organisation Raga Room challenges the conception of non-virtuosic musicality of female artists and British-trained performers more generally, as well as the concert hall context developed in colonial India and is highly innovative in the UK's South Indian music scene. An online concert platform developed by second-generation violinist, Kiruthika Nadarajah, Raga Room is a digital concert series for full-length Carnatic performances by musicians who have learned in diasporic settings (see Raga Room 2018). The concerts are performed at the organiser's house, and are broadcast live over YouTube. The platform was crowdfunded in order to give opportunities to musicians to perform full-length Carnatic concerts, including extended forms such as the Ragam Thanam Pallavi. After seven broadcasted concerts and one live performance at the Southbank Centre, more female musicians performed the Ragam Thanam Pallavi than their male counterparts. The organiser felt that these extended forms, that require high levels of manodharma sangeetham, are not prioritised in diasporic performances and so Raga Room provides a space for ambitious second-generation musicians to demonstrate their technical ability, including Kiruthika's own. The Ragam Thanam Pallavi form is performed during a music arangetram ceremony in London, however, it is widely understood that the music teacher has pre-composed the supposedly improvised variations of the pallavi and swara passages performed by the music student.

In an increasingly globalised India, Chris Fuller and Haripriya Narasimhan suggest that Chennai's attraction lies in 'its perceived traditionalism, most evident in religion and cultural activity' and associated with India's 'cultural capital' in the face of cities such as Bangalore and Mumbai, which exude modernity and Westernisation $(2014,163)$. The musicians discussed here are not based in Chennai; however, strong connections are maintained between diasporic music scenes and the South Indian city. Many continue to receive music lessons from eminent gurus in Chennai through annual visits to the city and through online Skype lessons. Through such tuition, migration and the Internet, ideals perpetuated from the Chennai Carnatic music scene are spread, and even challenged in diasporic settings. 


\section{New creativity in diasporic settings}

To demonstrate new creativity among female musicians, the following discussion focuses on musical examples by two British-Sri Lankan Tamil musicians, both of whom have a Carnatic musical education having learned to sing and play the veena. Both Mithila Sarma and Abi Sampa use their musical foundations in Carnatic music to break into the mainstream music scene whilst also engaging with community-based scenes and the Tamil independent music scene as well as the British Asian music scene. While also highly engaged with the Carnatic musical system and style, the musicians reveal virtuosity, individuality and new creativity. These examples are prominent in the music scene and distinctive in both approach and contribution to female creativity and performance. Sampa's use of Carnatic music is demonstrated in her cultivation of an idiosyncratic popular style that challenges feminine ideals more implicitly through the medium of performance and composition. Sarma's approach is more explicit; she actively seeks to challenge traditions and social issues through creative musical collaboration, composition and performance.

\section{Mithila Sarma and Subduction Zone}

The first example, the music and dance production, 'Subduction Zone' by Mithila Sarma, tells the story of growing up in British Tamil culture. 'Subduction Zone' was distinct from the Carnatic concerts organised by the first generation, often in suburban theatres or in temple halls around the capital. The foyer outside the performance space in the East London art centre, Rich Mix, was full of mostly second-generation British-South Asian young adults, aged in their twenties and thirties. The bar was doing good business, and once the doors opened to the performance space, the crowd sat on tiered seating, facing a space with instruments lining the perimeter. Sarma is rare in London's 
Tamil Diaspora in that she makes a living within the arts; many Tamil children are encouraged to pursue careers in medicine, engineering, law or economics while keeping music as semi-profession or a hobby. Sarma is an active performer, composer and collaborator with artistic directing experience at zerOclassikal - a project developing innovative composition in British South Asian music - and she works at Arts Council England. She is currently receiving tuition from the eminent artist and guru, Padmavathy Anandagopalan, in Chennai in order to strengthen her classical technique. Sarma has not had formal music education in any other system, so her new creativity is largely based on her knowledge of the Carnatic music system. She has also been inspired by her involvement with the South Asian Music Youth Orchestra (SAMYO) and Tarang - unique ensembles with musical arrangements reflecting the diversity of South Asian diasporic cultures in the UK. In an interview, Sarma told me: 'there's no clear direction as to how it all happens [the creative process]... when I think about it [the music], I'm thinking ragams, like "what ragam is going to go well with this piece". This scene is perfect for alairuppu [dance], I'm going to play this thirupukkal beneath it' (personal communication, November 2016). Following experimental Carnatic vocalist, O. S. Arun's model, Sarma gives the example of her thought process behind a scene based on East London life in which she pairs an alairuppu (an invocatory dance piece) with a thirupukkal (a Tamil devotional temple song for the God Murugan). With both the dance and the song being rhythmic in character, based on complex metres, and mutual in their invocatory and devotional function, the pieces are often paired in classical performances but are re-imagined in this diasporic context.

'Subduction Zone' was the result of a commission by Rich Mix, looking for works to address the social and political issues of East London through music, dance and theatre. The name of the production gives an indication to both the themes tackled and the musical and dance content; the subduction zone being the place of the convergence and tension of two tectonic plates, with the potential coexistence of both or submergence of one of them over the other. These plates act as 
metaphors for competing cultural identities and internal conflict in this case, reflected in the musical and choreographed content. The production brought together Carnatic and Hindustani musicians, popular musicians and classical and street dancers, all of whom Sarma previously knew. Influenced by the male-dominated Asian Underground, by Nithin Sawhney and Talvin Singh, and by the American-Tamil singer Sid Sriram, Sarma not only creatively experiments with her Carnatic music background, she also explicitly addresses issues of sexism, feminism, human love and sex in her production through themed and choreographed dance and through a metaphorical choice of songs, contrary to the ideals of Indian nationalist femininity. Sarma also challenges ideas of the standardised concert format and concert rules in her performance, as well as attitudes towards traditional dress. In an interview, Sarma questioned why a thillana - a dance piece - has to come at the end of a concert and why she has to wear a sari when she plays Carnatic music (personal communication, November 2016). In Sarma's performance, these questions challenge bigger issues in the music scene through non-conformance to 'traditional' conventions, such as the concert format that came about as a result of colonial influence and representations of sari-clad women.

Carnatic repertoire (which overlaps with Tamil repertoire in complex and contested ways), raga melodic frameworks, talam beat-cycles, instrumentation and the Sanskrit, Telugu and Tamil languages were at the basis of the production. These musical elements were performed by an ensemble of veena, Carnatic voice and Euro-American popular voice (by the same female vocalist), live electronics and synths, cello, bass guitar, cajon, mridangam. Along with the female voice, the veena was central to and foregrounded in this instrumentation, and it was used innovatively in building musical layers through ostinatos, chords and arpeggios. The veena was also used its traditional role in raga melodic and improvisatory performance. Classical repertoire often heard in traditional concerts was recontextualised in 'Subduction Zone' to reveal the themes of Sarma's story. For example, the second piece, 'Day Break', starts with the suprabhatam prayer usually sung in temples to wake the deities, with a backing of the shruti drone and with the female dancer on-stage 
waking up in her East London home, getting ready, and leaving the house after being reminded to complete pooja. The piece segues into 'Dance class', where Thyagaraja's highly-classical and devotional composition, 'Entharo Mahanubhavulu', was used to reveal the story of growing up in London and attending classical dance and music classes. Other pieces based on Carnatic music repertory include 'Play Doll', based around Papanasam Sivan's devotional 'Naan Oru Vilayattu'. The song's lyrics ask the Mother Goddess Uma if the singer is a toy doll to her, but Sarma uses this to show the complexity of parental expectations and relationships. Performed in its original melodic form and style, the song is sung above a foundation of a sampled veena chord loop, synths and electronics. Further into the piece, a veena improvisation in raga navarasa kannada is superimposed onto this innovative foundation. The asymmetrical raga navarasa kannada is traditionally said to be particularly well suited to veena in Carnatic music and Sarma maintains the integrity of the raga in her performance, something which she believes cannot be compromised in experimental and 'fusion' arrangements (personal communication, November 2016).

The story featured a piece entitled 'Love', which focused on human, rather than devotional, love. The female voice sings Tamil poetry in the iconic South Indian vocal style, with the cello providing counter melodies over a veena ostinato recorded on a loop pedal. After the Tamil verse, Sarma plays a virtuosic solo veena improvisation in raga behag, an asymmetrical North Indianderived raga associated with romance. The musical setting is combined with bharatanatyam and street dancing. While the recontextualisation of Carnatic music here is quite extreme in some ways, the music that is at the heart of the production is unmistakably grounded in the Carnatic music system, repertoire and stylistic delivery of raga. Sarma states that 'you stay classical, but you expand those boundaries' rather than claim these experiments are no longer considered as being Carnatic music (personal communication, November 2018). While Subduction Zone was not approached as a classical production, Sarma says that difficulties with the reception of such projects arise when traditional customs surrounding Carnatic music and its performance are challenged: 
Classical [music] for them is traditional, and then once you break tradition it's no longer classical. That's what it is, splitting the words traditional and classical ... classical music is literally what we learn when we grow up, it's got set rules, it's got set characteristics, I'm not talking about performance structure or anything like that, I'm talking from a basic 7 notes ... and you have your 72 melakarta ragas, you've got hundreds of ragas from it, you've got your compositions, you've got your varnams, keerthanams, your swarams. I think that's basically it. For me, its raga and tala, that is what classical music is (personal communication, November 2016).

Sarma argues that it is the musical system, not the performance conventions or instrumentation that determines Carnatic music, and therefore breaking such conventions while maintaining the musical rules of Carnatic music retains its classical aesthetic. This shift in Carnatic music is grounded in the British-Asian classical music scene, in finding relevant and accessible means to perform the music to broad audiences, including the large second-generation demographic.

\section{Abi Sampa and Raag'n'Blues}

The second example is 'Raag'n'Blues' by Abi Sampa. Although her main profession is not within the arts, she regularly performs in various collaborations in venues across the UK, including London's Rich Mix and Southbank Centre, and on the BBC Asian Network radio station; and she posts her latest musical experiments on social media. Sampa's virtuosic musical style of combining EuroAmerican songs with her Carnatic music background was revealed to the mainstream with her participation in the BBC broadcast of 'The Voice UK' singing competition in 2013. For instance, she uses raga alapana - improvisatory unfoldings of a raga - as short extemporisations before the start of Euro-American popular songs - such as Oasis' 'Stop Crying your Heart Out' (see BBC 
2013), and featuring the integration of Carnatic gamaka ornaments in pop-style melismas and virtuosic kalpana swaram solfège passages in bridge sections. Her current projects involve her voice, electric veena and harmonium with her band, blending influences of Qawwali, Carnatic and Euro-American popular music. There is a fluidity between the combination of popular song, Carnatic music and the associated stylistic characteristics resulting from Sampa's Carnatic musical education and her listening to Euro-American popular styles while growing up in London. In a similar way, Sarma says her work is 'an amalgamation of everything I have ever listened to and everything I enjoy listening to’ (personal communication, November 2016).

Sampa's 'Raag'n'Blues' is a version of Thyagaraja's 'Nagumomu Kanaleni', a virtuosic and newly creative display of the staple Carnatic song. This version is distinct from M. S.

Subbulaksmhi's rendition described above. The performance of this piece is captured on a video clip posted on Sampa's artist Facebook page, as part of an ongoing series of experimental improvisations and arrangements on the electric veena. The video is self-recorded at the artist's house, with the backdrop of her belongings rather than a stage or religious shrine, as is often the case with veena performance. This is a solo veena performance in Sampa's home, reminiscent of the domesticity of middle-class female veena players of the mid-twentieth century. While the video is filmed and posted from her home, Sampa's 'Raag'n'Blues' video received 3.2 million views, with comments on the performance from international followers (see Sampa 2017). In contrast to the colourful silk sari and plaited hair which consist of the usual attire for a female musician playing the veena in Tamil community-based performances and Carnatic concerts, Sampa wears black skinny jeans, a navy shoulder-less top, socks, and her hair is untied. Sampa plays 'Nagumomu' on the electric veena with a distorted and delayed sound effect through a Marshall guitar amp. Over an ostinato that Sampa pre-recorded on the veena and then looped via a loop pedal, Sampa plays the piece's pallavi thematic line which is then varied through improvisation. Importantly, and as in much of Sarma's music, there is no shruti drone which is otherwise considered as a fundamental of Carnatic musical 
performance as a point of reference and return. Instead, the ostinato loop functions as the foundation of the piece. Unlike M. S. Subbulakhmi's rendition, Sampa's version of 'Nagumomu' is a solo performance; there is no accompanying violin, mridangam or ghatam. The video audibly and visually places Sampa in the foreground of the performance.

Sampa plays in the song's original raga abheri (Sa, Ga2, Ma1, Pa, Ni2, Sa, Sa Ni2, Dha2, $\mathrm{Pa}, \mathrm{Ma} 1, \mathrm{Ga} 2, \mathrm{Ri} 2, \mathrm{Sa})$. Raga abheri's arohana ascending scale is the same as the minor pentatonic 'blues' scale. Linking the soundworlds of Carnatic music and iconic blues improvisation heard in blues, jazz and various Euro-American popular styles, the overall tone of the veena sounds like a solo electric guitar with the characteristic gamaka ornaments and treatment of raga abheri. Sampa makes use of the blues scale within raga abheri, adding some additional 'blues' licks and blues notes, such as the Ma2 in several places and thus completing the full hexatonic blues scale (see the circled notes in figure 1). The transcription below (figure 1) shows up to half way through the performance (from 0'00" to 0'59"), showing three distinct sections: first, the blues style 'alapana' of raga abheri (playing only the 'blues scale' arohana notes); second, the recitation of the song's main pallavi theme which adheres fully to raga abheri; and third, the development of the pallavi theme into the improvisation based again on only the notes of the 'blues' scale arohana. 

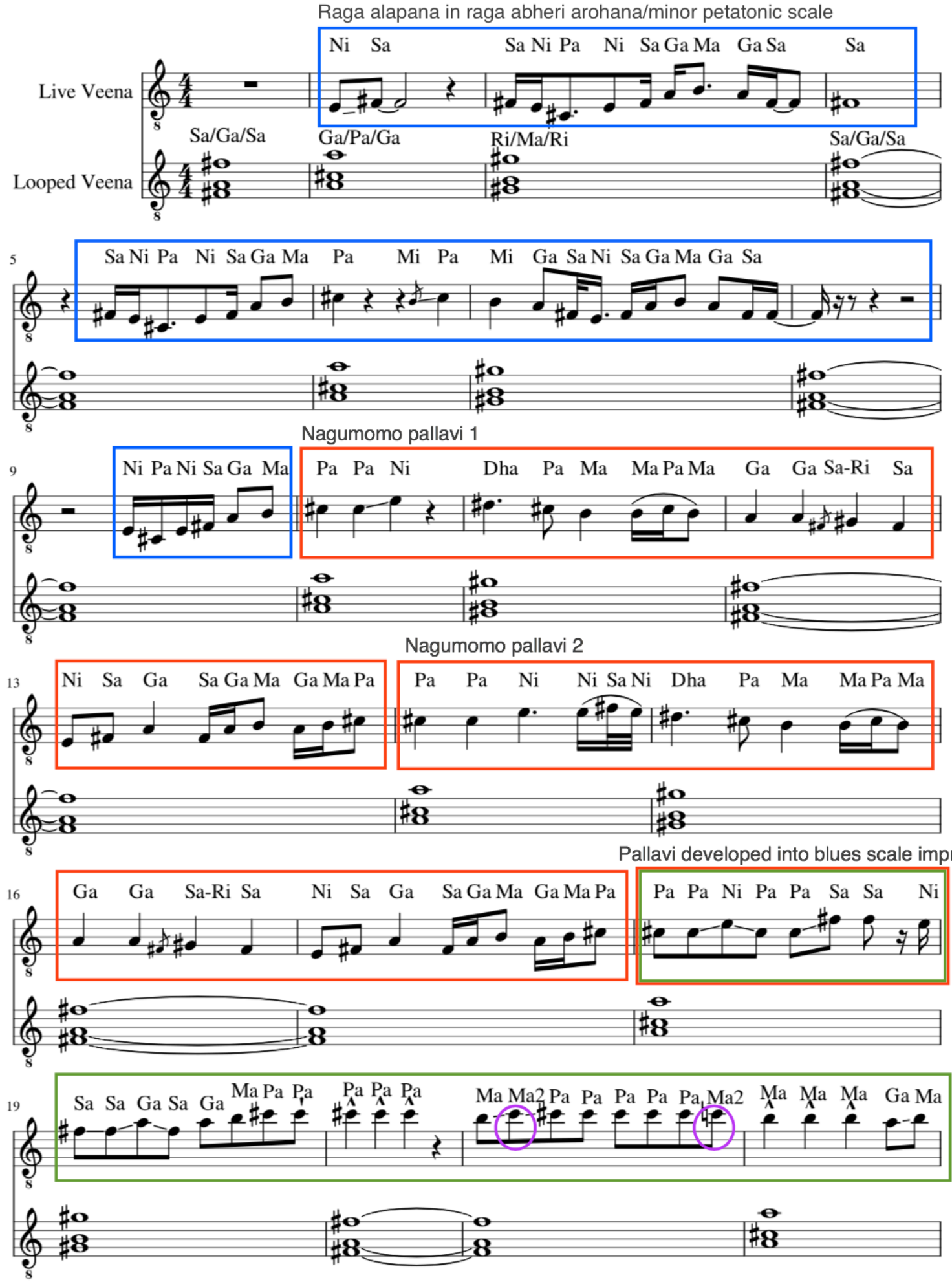


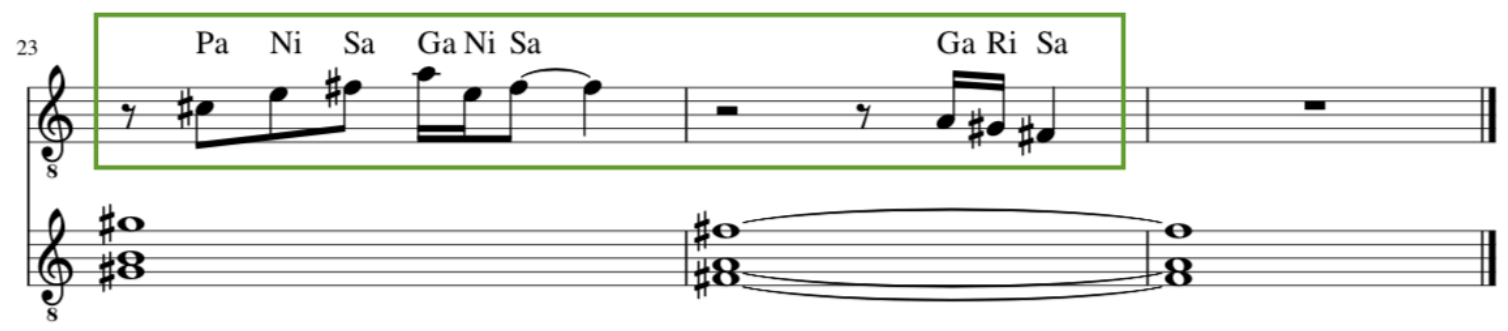

Figure 1: A transcribed excerpt in sargam and stave notation from 'Raag'n'Blues'. The transcription places Sa as F\# as in the original video. The sargam notation here refers to raga abheri (arohana ascending, Sa, Ga2, Ma1, Pa, Ni2, Sa, and avarohana descending, Sa Ni2, Dha2, $\mathrm{Pa}, \mathrm{Ma} 1, \mathrm{Ga} 2, \mathrm{Ri} 2, \mathrm{Sa})$.

One of Sampa's Facebook followers referred to this piece as 'veena shredding', linking the ancient Carnatic instrument to the male-dominated practice of rock guitar playing. While the response to the piece was largely positive, some Carnatic musicians and listeners were upset by Sampa's treatment of raga abheri and her inclusion of blues, or 'western', notes (Ma2). Such sentiments were expressed even though abheri is considered a 'bhasanga raga', so that it may include an additional note that is not in its parent scale. Her clothing also provoked comments on her wearing socks and non-conformance to the 'Hindu culture of the veena': the instrument is strongly associated with Goddess Saraswati and, therefore, with ideals of South Asian feminine appearance. This response, however, reveals ongoing tensions between newly creative treatment of Carnatic music in London and the Carnatic music scene, particularly in Chennai, and ongoing attitudes that emerged during colonialism.

\section{Conclusion}

The examples discussed above show female musicians working within and referencing their Carnatic music education, retaining an 'Indian' sound and appropriating Euro-American styles into 
their new creative projects. Their creative processes show a shift from an aesthetic that was responsive to colonialism in India to highlight the everyday sounds in Britain that influence them. They highlight issues of cultural hybridity in a diasporic community that uses Carnatic music to portray an essentialist sense of Tamil identity. The Carnatic music system, repertoire and style are at the foundation of the work, suggesting that these female artists retain a certain role as 'bearers of tradition'. They are, however, at the forefront of exploring a broader, unrestricted creative practice within the Carnatic music system in relation to expanding its use, and reaching out to become established as artists within London's global music scene.

Bakrania suggests that 'a woman who becomes too British risks being seen by her community as not only inauthentic but also traitorous' $(2013,167)$. Responses by more conservative Carnatic musicians suggest that new creative projects are considered 'inauthentic' or even 'traitorous'; or, as Sarma suggests, no longer classical if the surrounding traditions are broken. Within London's Tamil diasporic community, these artists have received largely positive responses as their projects are based on a Carnatic music education and maintain connections with the broader Tamil Diaspora, particularly the second-generation. Through their experimental styles, these artists challenge ideals of South Asian femininity and break away from rigid notions of the Carnatic music aesthetic.

These musicians represent their senses of British-Tamil identities and their creativity reflects cultural hybridity. Their shifts from conventional Carnatic style also shows how they are highly empowered female musicians, a gendered dimension of decolonizing processes. Their individual creative processes reflect broader social and cultural movements: postcolonial migration and diasporas, the transnational dimensions of musical practices, the acknowledgement of 'home' as a myriad, complex concept, shifts in gender roles, and current challenges to gender inequality. 
In her work on diasporic musical performance in the UK, Tina K. Ramnarine emphasizes that looking at everyday creative decision-making can reveal intricacies beyond population movements, resettlement and culture contact in order to move towards politically articulated readings of social relations and creative processes $(2007,7)$. Female performance practices are changing to an extent in South India too and these resonate with those in London. New creative projects by female artists in both contexts can be read as revealing distinctly feminist acts of creativity. These acts challenge gender roles, ethno-national identities and cultural expectations. These artists are contributing to creative music-making practices in the decolonizing era by reconfiguring gender issues in Carnatic music, with the potential for forging new directions in creative expression.

\section{Notes}

1. YouTube comments on Raman's videos include: 'a new revolution in Tamil devotional songs' (Karthikmein), 'New era for Tamil devotional songs, no words Susheela!!! simply great!!! just do more!!!' (Kayan Velauhtam), 'a very special voice and style. It will take some more years to appreciate her style since in Chennai people are orthodox and conservative. Well done madam' (Thygarajan Srinivasan), 'This is a real prostitution of a noble Karnatic music. Never heard [raga] Shanmukhapriya has been so distorted. Many of the lines are totally out of pitch! God save music from these people' (Jayaprakash Panicker).

\section{References}


Bakrania, Falu P. 2013. Bhangra and Asian Underground: South Asian Music and the Politics of Belonging in Britain. Durham and London: Duke University Press.

BBC. 2013. “The Voice UK 2013 | Abi Sampa performs 'Stop Crying Your Heart Out' - Blind Auditions 6 - BBC One”. Accessed 12 September 2018. https://youtu.be/XqZ6y60ZVNk

Chatterjee, Partha. 1989. "Colonialism, Nationalism, and Colonialized Women: The Contest in India." American Ethnologist 16 (4): 622-33.

1993. The Nation and Its Fragments: Colonial and Postcolonial Histories. Princeton, N.J: Princeton University Press.

Daniel, E. Valentine. 1996. Charred Lullabies: Chapters in an Anthropography of Violence. Princeton, N.J : Princeton University Press.

[Deccan Chronicle]. 2017. 'Art, culture should help us de-baggage our identities, says TM Krishna'. Deccan Chronicle. 25 November 2017. Accessed 12 September 2018.

https://www.deccanchronicle.com/entertainment/music/251117/art-culture-should-help-usde-baggage-our-identities-says-tm-krishna.html

Fuller, C. J., and H. Narasimhan. 2014. Tamil Brahmans: The Making of a Middle-Class Caste. Chicago and London: University of Chicago Press.

Hornabrook, Jasmine. 2017. "South Indian Singing, Digital Mediation and Belonging in London's Tamil Diaspora”. Journal of Interdisciplinary Voice Studies 2 (2): 119-36.

Kaur, Seetal. 2016. 'Review of Subduction Zone'. Pulse. Winter 2016, 22. 
Lakshmi, C. S. 2000. The Singer and the Song: Conversations with Women Musicians. New Delhi: Kali for Women

Murthy, Dhiraj. 2009. 'Representing South Asian alterity? East London's Asian electronic music scene and the articulation of globally mediated identities'. European Journal of Cultural Studies 12 (3): 329-348.

M. S. Subbulakshmi (uploaded by dartdisah). 2008. 'Nagumomu Kanaleni (Abheri)'. Accessed 12 September 2018. https://youtu.be/TmZ5U9SfDNk

Panchapakesa Iyer, A. S. 2008. Gānāmrutha Bōdhini: Sangeetha Bāla Pādam. Chennai: Gānāmrutha Prachuram.

Raga Room, 2018, Accessed 12 September 2018. https://www.youtube.com/channel/UCgra7S3AAdoM2Sa9N32HKA

Ramnarine, Tina K. 2007. 'Musical Performance in the Diaspora: Introduction'. Ethnomusicology Forum16 (1): 1-18.

Reed, Susan A. 2010. Dance and the Nation: Performance, Ritual, and Politics in Sri Lanka. Madison: University of Wisconsin Press.

Russell, Jane. 1982. Communal Politics under the Donoughmore Constitution 1931-1947. Dehiwala: Tisara Prakasakayo.

Sampa, Abi. 2017. 'Raag'n'Blues'. Accessed 12 September 2018. https://www.facebook.com/AbiSampa/videos/808353182676137/

Shukla, Sandhya R. 2003. India Abroad: Diasporic Cultures of Postwar America and England. Princeton N.J : Princeton University Press. 
Srinivasan, P. 2012. Sweating Saris: Indian Dance as Transnational Labor. Philadelphia: Temple University Press.

. 2016. 'Becoming Subbulakshmi by Dr Priya Srinivasan - performance based research'. Accessed 12 September 2018. https://vimeo.com/235829956,

Subramanian, Lakshmi. 2006. From the Tanjore Court to the Madras Music Academy: A Social History of Music in South India. New Delhi: Oxford University Press.

Weidman, Amanda J. 2003. 'Gender and the Politics of Voice: Colonial Modernity and Classical Music in South India'. Cultural Anthropology 18 (2): 194-232.

.2006. Singing the Classical, Voicing the Modern: The Postcolonial Politics of Music in South India. Durham and London: Duke University Press.

Wilson, A. Jeyaratnam. 2011. "Language, Poetry, Culture, and Tamil Nationalism.” In The Sri Lanka Reader: History, Culture, Politics, edited by John C. Holt, 459-470. Durham and London: Duke University Press.

\section{Figure 1 Caption:}

A transcribed excerpt in sargam and stave notation from 'Raag'n'Blues'. The transcription places Sa as $\mathrm{F} \#$ as in the original video. The sargam notation here refers to raga abheri (arohana ascending, $\mathrm{S}$

a 